\title{
Internalization of M ulticultural-Based Islamic Education: Sunni-Shia Synergy in Banjaran Bangsri Village, Jepara
}

\author{
Ahmad Saefudin \\ U niversitas I slam $\mathrm{N}$ ahdlatul U lama, Jepara, Indonesia \\ ahmadsaefudin@unisnu.ac.id \\ Abdul M unip \\ UIN Sunan Kalijaga, Yogyakarta, Indonesia \\ abdulmunip73@yahoo.co.id \\ Khoirotul Laila U Ifa \\ U niversitas I slam N ahdlatul U lama, Jepara, Indonesia \\ ellaulfah74@gmail.com
}

\begin{abstract}
This research aims to reveal the role of Sunni-Shia Islamic educational institutions in building multiculturalism in a pluralistic society. So far, the Sunni-Shia relationship has been depicted in a conflictual scheme. The research method was qualitative from the sociology of education perspective. Through in-depth interviews, participatory observation and documentation techniques, this study showed that the atmosphere of peace between Sunni-Shia in Banjaran is reflected in the social works of humanity, organizations and Islamic educational institutions. Multicultural education cannot be separated from the role of formal and non-formal Islamic education institutions such as TPQ A/Husainiah (Shia), TPQ Ma'arif $17 \mathrm{KH}$. Muhammad Arif (Sunni) and MI Mabadil Huda (Sunni). The kinship also has a contribution to maintaining Sunni-Shia harmony in Banjaran. Theoretically, this research contributes to the development of multicultural I slamic education models in rural. Practically, it is beneficial for Islamic education institutions in building awareness of multiculturalism and tolerance between religious sects.
\end{abstract}

Keywords: Islamic education, multicultural awareness, Sunni, Shia, Jepara 


\begin{abstract}
Abstrak
Riset ini bertujuan mengungkap peran lembaga pendidikan keagamaan Sunni dan Syiah dalam membangun kesadaran multikultural masyarakat yang hidup di tengah kemajemukan. Selama ini, relasi Sunni-Syiah digambarkan dalam skema konfliktual. M etode penelitian yang digunakan ialah kualitatif dengan memanfaatkan sosiologi pendidikan sebagai perspektifnya. M elalui wawancara mendalam, observasi partisipatoris, dan teknik dokumentasi, penelitian ini menyimpulkan bahwa atmosfer kedamaian antara pengikut Sunni dan Syiah di Banjaran tercermin dari kerja-kerja sosial kemanusiaan, organisasi, serta lembaga pendidikan keagamaan Islam. Penanaman kesadaran multikultural di sana tak bisa dilepaskan dari peran lembaga pendidikan Islam formal maupun non-formal seperti TPQ Al-H usainiah (Syiah), TPQ Ma'arif $17 \mathrm{KH}$. M uhammad Arif (Sunni), dan MI M abadil Huda (Sunni). Faktor hubungan kekerabatan juga mempunyai andil besar dalam menjaga ikatan harmonis Sunni-Syiah di D esa Banjaran. Secara teoretik, riset ini memberikan kontribusi pengembangan model pendidikan Islam multikultural di kawasan rural. Secara praktis, bermanfaat bagi institusi pendidikan Islam dalam menyebarkan kesadaran kemajemukan dan toleransi antar sekte keagamaan.
\end{abstract}

Kata kunci: Lembaga pendidikan Islam, kesadaran multikultural, Sunni, Syiah, Jepara

\title{
A. Introduction
}

Religious education institutions, in this context, are Islam, have a central function in fostering awareness of pluralism in the life of the social culture. Religious institutions are believed to be able to shape character and morals. It also determines the life philosophy of the community. However, complex, cultural norms and intersect are influenced by religion. As a social and cultural phenomenon, religious institutions do not stand alone. Its appearance in the public sphere is full of ideological content. Unfortunately, there is a kind of accusation that the role of religious institutions is only concerned with the issue of mahdlah worship by as well as dismissing a more substantive function, namely being an instrument for solving social and national problems ( social worship). (M arzuki, 2018). Functions of religious institution do not run well so it is just for doctrine medium ( M ahmudah, 2017; Saparudin, 2017).

H owever, these allegations do not appear to apply to religious education institutions in Banjaran Village, Bangsri District, Central Java. O ne of the patterns of the development of harmonious life between Sunni and Shia groups is based on the foundation of education. As a representation of Sunni Islamic educational institutions, Taman Pendidikan AI-Q uran (TPQ) 
and Madrasah Diniyah Ma'arif 17 M uhammad Arif NU are active in teaching multicultural awareness to their students. Meanwhile, Shia environment is represented by TPQ AlH usainiah. $O$ ne of the routine activities of Shia residents in that place is Fatimiyahan, which holds recitation every two weeks. Uniquely, this forum was not only attended by Ahlulbait, but also Sunni schools affiliated with $\mathrm{N}$ ahdlatul Ulama and Muhammadiyah organizations (interview with Zakiyyah, a Shia leader in Banjaran Village, 12 September 2019).

Judging from the distribution of 13 dukuh (sub-villages) that occupy Banjaran Village, the most dominant Shia adherents live in Dukuh Candi, exactly in $R T 01 R W 02,03$, and 04. Apart from Banjaran Village, the Shia community in Bangsri District is also found in Kauman Village. Sheikh Abdul Q adir Bafaqih is a charismatic scholar figure who first spread Shia ideology in the Jepara area. Genealogically traced, the contribution of Sheikh Abdul Q adir Bafaqih has been recognized by Bangsri community since 1983, since he founded the Sunni Islamic boarding school "Al-K hairat". In addition to accommodating many santri from various regions, his relations with parties outside pesantren are quite extensive. $N$ ot surprisingly, he often gets shipments of books from Dar al Tauhid Islamic Boarding School in M iddle East which is affiliated with the sect about Shia. It may be that this intensive interaction with the discourse of loneliness influenced him to convert from Sunni to Shia ideology. Until now, Shia in Banjaran Village continues to grow. In terms of quantity, it can even be said that it is quite a lot because it reaches around 300 people. H owever, in performing religious rituals, they are no longer secretive by applying taqiyyah. There is no exception on 10th Asyuro Commemoration ceremony which according to the Shi'ah is very sacred (Sulaiman, 2017, p. 25).

The harmonious relationship between Sunni and Shi'a in Jepara is certainly a hundred and eighty degrees different from the stories experienced by the Shia community in other places, such as in Pekalongan and Sampang. (H astuti \& M aulana, 2019; Ida \& Dyson, 2015; Khalilur Rahman, 2020; Rakhmat, 2015; Widyadara, 2015; Yunus, 2014). In those areas, the Shi'a-Sunni relationship was full of conflict. For example, the long Sunni-Shia enemies in Bangil, East Java in 2007-2011, the "bloody carnival" in Bondowoso, Puger, Karanggayam, Bluuran, Sampang, and Jember between 2006-2012 (Yunus, 2014; Saefudin \& Rohman, 2019b), and the attack on the Shia Islamic boarding school in Pekalongan, Central Java (Widyadara, 2015), Shia-Sunni confrontation in the international world involving many countries such as Afghanistan, Yemen, Jordan, and Lebanon (D oostmohammadi et al., 2012; Samii, 2006; W agemakers, 2020).

The research approach chosen was qualitative. The researcher tried to find a data description of the harmony of Sunni-Shia religious education institutions directly from 
Banjaran Village. The aim is to obtain data on the behavior and perceptions of research informants about planting multicultural awareness through educational institutions ( $H$ ardiansyah, 2010). The perspective used as an analysis tool is the sociology of education, which is a point of view that places history, geography, and the relations between social classes as the key to understanding class inequality in education (Reay, 2009, p. 402). The relationship discussed is the harmony of Sunni-Shia educational institutions in Banjaran Village in striving for multicultural awareness for each group. Through the sociological paradigm, the relationship between structure and agency that plays a role in fostering this social harmony can be identified. The researcher examined carefully each of the informants' actions, both Sunni and Shia, which showed elements of multicultural awareness (Lynch, 2001, p. 240). In a more radical perspective, the reproduction of knowledge carried out by Islamic educational institutions can only be understood through an interactional analysis scheme between educational unit institutions, state, and conomic structure of society. Thus, Sunni and Shia relationships can survive the dominant social practice (Giroux, 1983, p. 258).

Through participatory observation, researchers observed the characteristics of Banjaran Village community, their education, and local traditions, to the social harmony triggered by the role of Sunni and Shia religious education institutions. This data was enriched by the results of interviews with research informants consisting of 1) religious figures, namely the $\mathrm{H}$ ead of the NU Subdistrict, Shia leaders, Habib, Chair of TPQ Al-H usainiah, TPQ MA'arif NU teacher, and Islamic Religious Education teacher of MI Mabadil Huda Desa Banjaran. 2) community leaders, namely Banjaran village apparatus and youth. As a complement, researchers also used documentation techniques in the form of village profiles and photos of activities carried out by Sunni-Shia educational institutions in Banjaran.

The data collected was then analyzed in several stages. First, data reduction. The researcher chose the data that had been obtained, especially from its completeness, clarity of meaning, suitability, and relevance to the harmony of Sunni-Shia religious education institutions, including removing data that is not so relevant. Second, the classification stage. Researchers categorize the data from interviews, observations, and documentation into several sub-discussions to make it easier for the audience to read the research results. Third, verify. Researchers carefully checked the validity of field data through checking on the results of interviews, observations and documentation. Fourth, data presentation. Researchers narrated the field data descriptively, neither add nor subtract information from research informants. Fifth, conclusions drawing. The researcher concludes the research results as well as makes a theoretical claim on the problematization process of the problem. 
The academic problems were answered in this research includes two important points, namely how religious educational institutions originating from two different sects (Sunni-Shia) can run in harmony and why this inclusive practice seems to have become a habit in society.

Theoretically, this study is useful for the contribution of knowledge, especially in the field of multicultural Islamic education. For practical use, this review can be used as a best practice for Islamic religious education institutions in instilling the values of social harmony, awareness of pluralism and tolerance between religious sects. Throughout the search for the relevant literature, the academic discourse on Sunni-Shia relations never leaves the theme of conflict (M ulyono, 2012; Sahide, 2013; Yunus, 2014; Ida \& Dyson, 2015; Widyadara, 2015; H astuti \& M aulana, 2019), tolerance (Amaliyah, 2015; Sulaiman, 2017; Saefudin \& Rohman, 2019), ideology (Atharuddin, 2014; Rakhmat, 2015; M usolli, 2015; N ur \& Irmawati, 2019) and political identity (Anis, 2015; Kadir, 2015; Hodari, 2015; Yumitro, 2017; Gunawan, 2019). Very few researchers are interested in linking Sunni-Shia relations to the domain of educational institutions. M oreover, the scope is still very narrow. For example, the dissertation was written by M uhammad Andy Isya. He highlighted the issue of disparity in Sunni-Shia educational institutions in Pasuruan Regency (M uhammad Andi Isya, 2014; 2018). It is different from the review that is written by the researcher because it focuses more on best practice harmony between the two educational institutions. Therefore, the researcher involved the academic debates of the scholars above by showing new facts about the inclusive relationship between Sunni-Shia sects through Islamic educational institutions that have escaped their observation.

\section{B. Discussion}

\section{The frame of M ulticultural A wareness as the Capital Social of Sunni-Shia H armony}

Multicultural awareness is a condition that shows people's concern about diverse racial, cultural, ethnic, and linguistic groups (Banks, 2001, p. 202; Izzah, 2020; M asamah \& Zamhari, 2016). 0 ne of the figures who popularized this issue was James A. Banks, an educator from the U nited States who served as Director of the University of Washington's Center for Multicultural Education. For Banks, education must be designed to incorporate the knowledge, values, experience, and perspectives of the weak and marginalized (Banks, 1998, p. 15). In the context of this review, the community that is considered weak and often marginalized by the majority group is Shia followers. The Shia population is only about 10$15 \%$ of all M uslims in the world. They live in I ran, Iraq, Bahrain, and Azerbaijan. They can also be found in Afghanistan, Kuwait, Lebanon, Pakistan, Saudi Arabia, Syria, and Yemen. In Islam, 
Sunni and Shia are sects that have a long history of civilization. However, the ideological differences between the two ideologies sometimes trigger religious intolerance, political strife, and sectarian violence (Blanchard, 2010).

In a psychological review, the differences between Sunni-Shia can be broken down by changing community perceptions to minimize social conflicts caused by prejudice, stereotypes, and fanaticism. (Sari et al., 2020). O ne of them is planting multicultural awareness in each group covering three crucial areas: 1) awareness of world view, 2) knowledge and awareness of the world view of culturally different groups, and 3) use of intervention strategies that are appropriate to local culture ( $\mathrm{H}$ all \& Theriot, 2016, p. 36). Thus, it is important to understand how a discourse of knowledge is created and how it is closely related to factors of race, ethnicity, gender, and social class (Banks, 2014, p. 25).

Sunni-Shia social harmony, namely the process of interaction between adherents of religious ideas in Islam in Banjaran Village which is based on tolerance, understanding, mutual respect, and respect for one another. This attitude serves to reduce tensions and fractures in social relations (Wirata, 2018). It is undeniable that religious views that tend to be theologicalnormative will al ways clash when dealing diametrically with the historical-critical approach. In expressing religious practice, both Sunnis and Shiites at one point have standard and exclusive doctrinal arguments. H owever, at a different point, they also often carry out appropriations and negotiations so that their social regulators are not underestimated. The adjustment of these two different poles, by M. Amin Abdullah is termed creative tension, which is a process of creative tension that usually appears in religious communities that live under pluralistic banners (Abdullah, 1996, p. 4).

The existence of Shia in Jepara is relatively easy for other social organizations to accept, such as Forum Kerukunan U mat Beragama (FKUB) or Forum for Religious H armony, the Gusdurian N etwork, and $\mathrm{NU}$; the close social relationship between the family environment and the surrounding community, for example through maulidan ceremony (the birthday of the Prophet M uhammad), haul of the village figure M bah M uhammad A rif ( performed every 1 Syuro) and social services, such as HIKM AT ( Himpunan Peduli Umat) which was formed by Shia residents, Ikatan Remaja M asjid (IRM AS) or M uslim M osque Youth Association formed by the Sunni community, commemorating Indonesia's independence day (observation in Banjaran Village on January 22, 2020). O ne form of Sunni-Shia social harmony in Banjaran Village is the practice of Jami'ah M uawanah association. This cultural forum aims to help residents who are affected by death. Its initial aim was to erode the stigma between groups. But, over time, it turned into a cultural activity. In practice, they no longer question different 
schools of thought (interview with Fathirin, a Shia leader in Banjaran Village, December 25, 2019). This organization has regular events every Eid al-Fitr, namely halal bihalal among followers of religious beliefs (Sunni and Shia). It is usually done by holding a ceremony that involves many residents. The tradition of halal bil halal as a medium for meeting all members of Sunni and Shia society is a form of positive attitude from adherents of religious ideology in Islam. With the tradition of physical encounters between followers of religious beliefs, mutual forgiveness grows. Relations between communities are becoming more intimate and full of kinship. Because halal bilhala/ has a positive effect among heterogeneous people, this tradition has been preserved to this day (interview with Zabidi, $\mathrm{H}$ ead of the Banjaran Village NU Subdistrict, December 24, 2019). From a neuropsychic perspective, physical presence at such gatherings provides strength for both Sunnis and Shiites to increase the level of integration in heterogeneous layers of society (W aterworth et al., 2010, p. 19).

The social harmony of religious communities in Banjaran Village can be manifested through various attitudes: 1) Mutual tolerance, mutual respect, and tolerance between religious communities 2) Not forcing someone to embrace a certain religion/ sect 3) Carrying out worship according to their religion and 4) 0 beying religious regulations both in their respective religions and in the juridical laws and regulations in force (interview with Fathirin, Shia L eader of Banjaran Village, 4 N ovember 2019). In realizing Sunni-Shia social harmony in Banjaran Village, the role of community leaders has a very strong influence. The people of Banjaran Village are always enthusiastic about participating in religious activities that are oriented towards harmony. For example, carrying out routine activities by visiting each house in turn, such as neighborhood activities, hamlets activities, and congratulations to being famous. At a certain moment, they jointly celebrated hau/KH . M uhammad Arif, maulidan, and Sedekah Bumi ( alms for earth), Sunni-Shia followers inevitably meet in one forum.

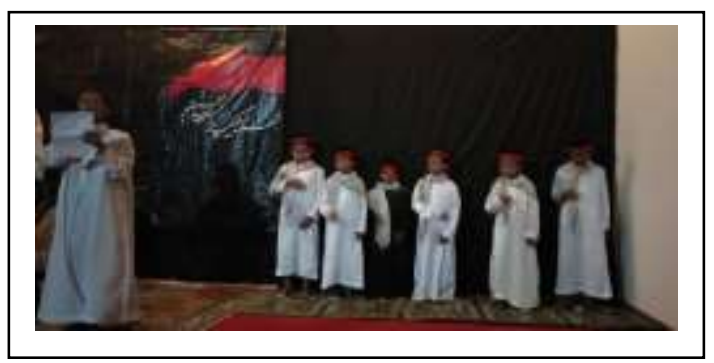

Figure 1. A shura activities carried out by the Syiah community at M usalla AI-H usain, Banjaran Village 


\section{The Role of Sunni-Shia Religious Education Institutions in Banjaran Village in Cultivating Multicultural Awareness}

The people of Banjaran Village believe in Islam as the basis for their belief in carrying out their daily life. There are two dominant Islamic schools of thought, namely Sunni and Shia. The Sunnis referred to here are followers of I slam affiliated with the mass organizations, NU and M uhammadiyah. M eanwhile, Shia is followers of Shia Itsna A sy'ariyah (Imamiyah). These different beliefs do not become a barrier to harmony among the residents. Even uniquely, there are also several houses whose residents are followers of different schools of thought. This is in line with the data from interviews conducted by researchers on February 20,2020, with $H$ amzah, one of the youths of Banjaran Village:

For example, there is a husband as a Sunni follower, but his wife is Shia. There are also Sunni fathers, but their children are Shia, and vice versa. But they still get along. A part from the mutual respect factor, the people here are still as one big family.

However, Hamzah objected to mentioning the names of the family members. Togetherness between members of the different schools of thought is also manifested in some socio-religious activities in the local area. $\mathrm{H}$ amzah gave an example, about the funeral prayer or tahlilan activities when a resident passed away.

If the residents who passed away were Sunni, then prayers and procedures were performed at M bah M uhammad Arif M osque. But if the one who passed away has a Shia sect, then we pray at M usalla AI-H usaini. People are used to praying for each other and did not see the school he studied in. They are the same (interview with H amzah, Banjaran Village Youth Leader, February 20, 2020).

This information was confirmed by another informant named $\mathrm{H}$ abib H usein, Imam of Rawatib Masjid M bah Muhammad Arif, Banjaran Village. According to him, togetherness between Sunni and Shia residents can also be seen at the tahlilan ceremony. Both followers of these different schools of thought came during activities to pray for the deceased.

When tahlilan activities took place, prayers were led by religious leaders from each school. For example, if the deceased is a Shia citizen, tahlil leader is a Shia religious figure. However, Sunni religious leaders have replaced them with prayer and vice versa. The point is that our social affairs are very harmonious (interview with $\mathrm{H}$ abib H usein, a Sunni Leader in Banjaran Village, February 22, 2020).

Whereas in other areas, Sunni and Shia groups experienced friction, even conflicts that resulted in casualties, in Desa Banjaran it was the opposite. The culture that appears is harmony. This can be seen when one of the two is carrying out a religious tradition or ritual, 
they respect each other by not forbidding the tradition. "Gathering events are such as in pregnancy, birth, aqiqah, circumcision, marriage, and death. The ritual is carried out by the owner of the party/events by inviting all citizens regardless of the different schools of thought" (interview with Zabidi, Banjaran Village Community Leader, February 22, 2020). The multicultural awareness of the residents is also seen in cooperation and community service cleaning places of worship and village tombs. "Usually once a month there is community service cleaning the environment. Work hand in hand each other in every activity. For example, the cooperation program for haul of ulama M bah KH. Muhammad Arif (interview with Abdullah, Community Leader of Banjaran Village, 23 February 2020). The closeness of this interaction creates an inclusive and tolerant attitude among the citizens. As explained by one of the informants:

Sunnis and Shiites, they are aware. Forcing beliefs to the others is a matter that can create conflict. Because belief in embracing a religious ideology is a personal problem that concerns the relationship between humans and God. So, whatever, want to be Sunni, or want to be Shia, the important thing is to live in harmony, good with others (interview with Zakiyyah, a Shia leader in Banjaran Village, February 23, 2020).

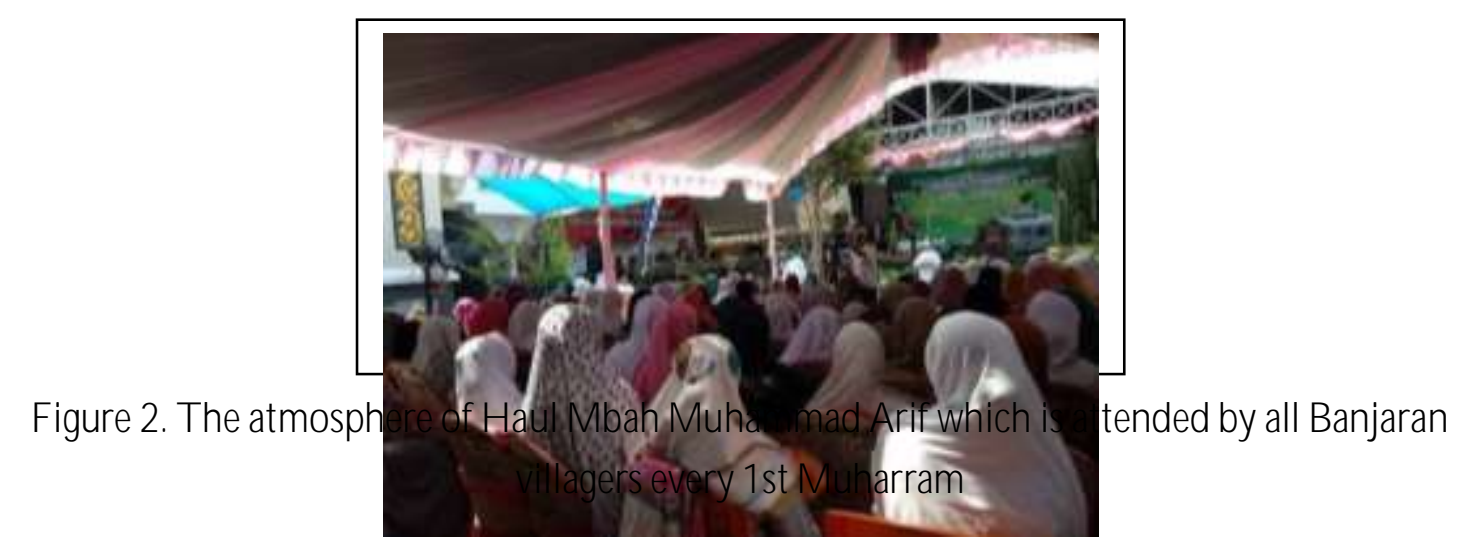

Zakiyah continued, the key to community harmony is reducing stereotypes. Prejudice against other groups will only lead to social disintegration. "To maintain harmony, one of which is by giving freedom of religion and inviting the public to deepen their respective beliefs without making a difference." (interview with Zakiyyah, a Shia leader in Banjaran Village, February 23, 2020). 
Judging from the development of the number of Sunni-Shia followers in Banjaran Village between 2017 and 2019, there are interesting facts that were found by researchers. This can be seen in the following table:

T able 1. D ata for Sunni-Shia Adherents in Banjaran Village

\begin{tabular}{cllll}
\hline No & Group & 2017 & 2018 & 2019 \\
\hline 1. & Sunni & 7.619 & 8.097 & 8.448 \\
\hline 2. & Shia & 650 & 600 & 580 \\
\hline & Amount & 8.269 & 8.697 & 9.028 \\
\hline
\end{tabular}

From the results of the data above, it shows that the people of Banjaran Village who follow Sunni teachings from year to year are increasing. After being tracked, it turns out that this is due to several factors. 0 ne of the most common factors is heredity and marriage. For example, someone is Shi'ah. Then he married a Sunni. So, he will change his understanding from Shia to Sunni. As for the Shi'ah sect, the opposite happened. From year to year, it decreased by approximately $2 \%$. Apart from the marriage factor, the cause is the migration of Shia people to other regions. $\mathrm{H}$ owever, the decline in the number of Shia residents is not a problem.

The kinship factor is also a key instrument of the closeness of Sunni-Shia relations. This is based on the explanation of Jazeri, one of the residents of Banjaran Village, "most of the Dukuh Candi Banjaran have blood relations, but have different understandings, and there is no problem." (interview with Jazeri, resident of Banjaran Village, 17 October 2019).

In the education domain, there are several Sunni and Shia-based religious institutions that support a harmonious climate of life for residents in Banjaran Village.

\section{a. TPQ AI-H usainiah}

TPQ Al-H usainiah is an Al-Q ur'an learning institution located in Banjaran Village, exactly at M usalla Syiah AI-H usaini. TPQ Al-H usainiah was developed in the 1980s. It was initially developed by $\mathrm{KH}$. Badawi and $\mathrm{H}$. Khadijah. They were students of $\mathrm{KH}$. Syeh Abdul Q adir Bafaqih. Based on the observations of researchers on February 28, 2020, the components of the learning system at TPQ Al-H usainiah are not much different from Sunni educational institutions. It consists of ustaz / ustazah, students, mushalla, and learning alQ ur'an. Santri are routinely given discourses on Shia studies. At TPQ AI-H usainiah, there are 5 female teachers and 50 students consisting of 17 male and 33 female students with an average developmental level of children aged 4-12 years. 
The vision of this institution is to prepare their students to become the Qur'ani generation, that is, the generation that loves the $Q$ ur'an as a reading as well as a daily view of life (TPQ AI-H usainiah Profile Document, 2020). To achieve these goals, TPQ AI-H usainiah applies a more religious practice learning curriculum. For example, the practice of reading compulsory and sunnah prayers, memorizing verses from the Al-Q ur'an, daily prayers, and practicing drama, poetry, fairy tales, telling stories about the prophet and previous Shia warriors (interview with Siti Khadijah, Chairperson of the TPQ AI-Husainiah Syiah, 28 February 2020).

The teacher also introduces the values of plurality to students and respect for others regardless of their form is a necessity cecause diversity has been created by God. " $A$ difference should be used as a way that is Allah giving the blessings of diversity between us to complement each other." (interview with Siti Khadijah, Chairperson of the TPQAl-H usainiah Syiah, 28 February 2020).

When the researcher interacted with one of the informants from Shia and asked their understanding of $Q$ uran, there was not the slightest answer that led to an indication of tahrif (assuming that the current Q uran is fake) like the accusation of the Majelis Ulama Indonesia (M UI) or Indonesian U lema Council. (Amin et al., 2013). "Understanding the Qur'an is the key to mastering Islamic religious knowledge in a broad sense. The generation of Shia M uslims must be based on the understanding of the Q uran according to the instructions of Allah, the prophet, and the Imam." (interview with Siti Khadijah, Chairman of TPQ Al-H usainiah, Banjaran Village, 28 February 2020). As a counter-narrative against the allegations of Shia deviance, the Indonesian Ahlulbait Team (ABI) published two important books which were given the foreword by two quite popular Sunni figures, namely M. Q uraish Shihab (expert on Qur'anic commentary) and Lukman Hakim Saifuddin (who was then serving as Minister of Religion of the Republic of Indonesia). Referring to the thoughts of the two moderate figures, the negative labeling of Shia is caused by the lack of understanding and misunderstanding of outsiders who also monopolize the truth by using their perspective. Besides, groups that are opposite to Shi'ah tend to be reluctant to interpret a difference in a varied diversity corridor. Rather, it is directed at contradictory matters which in turn spark conflict (Indonesia, 2012, 2014; Zafi, 2020).

\section{b. TPQ Ma'arif 17 M uhammad Arif}

TPQ M a'arif 17 M uhammad Arif is a $Q$ uran learning institution based on $N$ ahdlatul Ulama which is located in Banjaran village, DukuhC andi. This institution or community group 
that was founded in the 1970s provides non-formal education. $\mathrm{Hj}$. Siti U mairoh, the daughter of the prominent M bah KH. M uhammad Arif, was a Sunni figure who built Banjaran Village. The purpose of its development is to provide teaching to read the $Q$ uran or village people term it with the Q uran followed by early childhood. In addition to reciting the Q uran, TPQ also teaches the basic principles of Islamic teachings ahlusunnah wal jamaah NU's perspective ( results of observation in Banjaran Village on February 28, 2020). There are 3 educators who support 30 students. Twenty women, and the rest men. The teaching of the Sunni TPQ is divided into two groups, namely the early childhood group for TPQ M a'arif from around 4-6 years of age (Kindergarten / Elementary School). M eanwhile, the students at Madrasah Diniyah Ula M a’arif N U are 7-12 years old.

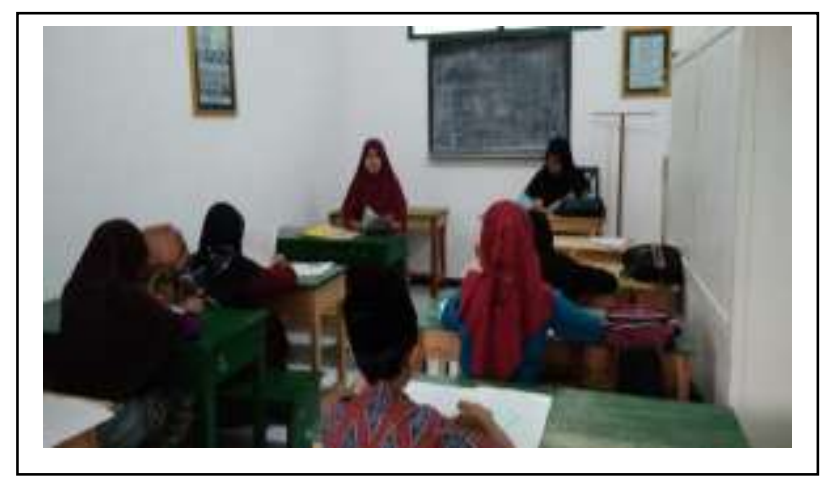

Figure 3. The learning process at TPQ M a'arif 17 M uhammad Arif

The components of the education system in TPQ include teachers, students, buildings, mosques, the Q uran, books, books, libraries, and community development centers (observations in Banjaran Village on February 28, 2020). The curriculum applied is reading and writing the $\mathrm{Q}$ uran, reciting tajwid, and memorizing prayer prayers, as well as daily prayers to be practiced in everyday life. "In addition to educating students in reading and writing the Qur'an, it is also hoped that teachers can implement children's morals to become morals like the Al-Q ur'an which always fortifies themselves from sayyi'ah (bad) traits." (interview with Umaroh, Chairman of the Banjaran Village Ma'arif Institution, 28 February 2020). In developing learning, TPQ Ma'arif applies rote and practice more. therefore, every year the number of students increases. The students also admitted that the learning process carried out by the ustad and ustadzah was quite fun. The proof, they can memorize several juz Al-Q ur'an and short surah.

The multicultural education values taught by TPQ Ma'arif 17 teachers to students are not explicitly included in the content of the learning curriculum. However, it is more of a 
hidden curriculum. For example, teachers teach students to always be prejudiced against their peers, regardless of whether they are Shi'a or Sunni. They are invited to respect, appreciate, cooperate and help each other. The teachers and students showed mutual respect when invited by the Shia-affiliated TPQ Al-H usainiah for reciting recitation and prayer together. They gathered in a forum without feeling awkward. "After studying, the children from TPQ M a'arif and TPQ Al-H usainiah played together," (interview with Faizin, the teacher of TPQ Ma'arif $17, M$ arch 3, 2021).

Likewise in religious traditions, TPQ Ma'arif and TPQ Al-H usainiah are relatively harmonious. Through inclusive religious studies, Shilites and Sunnis both understand the substance of peace in religion. M ore importantly than that, the blood relationship factor also greatly influenced the Shi'ah-Sunni relations in Banjaran Village. Thus, they both respect different religious traditions. As said by Faizin, as the administrator of the following religious activities in Banjaran Village:

The TPQ Ma'arif santri were always kind to their Shia brothers. The proof is often playing together after school. Because most Sunni and Shi'ah santri still have blood ties. So, from the santri family themselves, they are accustomed to respecting the traditions of the Shi'ah brothers (interview with Faizin, the teacher of TPQ Ma'arif $17, M$ arch 3, 2021).

The reduction of prejudice was also shown by the TPQ Ma'arif 17 teacher to all students regardless of their religious background. Sunni and Shi'a children each have the right to study with anyone. That way, the children of TPQ Ma'arif 17 were no longer surprised, they were even used to the Shi'ah tradition in Banjaran which was held every month (Fatimiyah).

As a TPQ educator, you must be able to set a good example. Be respectful of others, respect differences of opinion, and in friendship, do not differentiate between religion, ethnicity, race. Everything here is the same. Because we are all brothers (interview with U mairoh, the teacher of TPQ Ma'arif 17,7 M arch 2021).

\section{c. Madrasah Ibtidaiyah (M I) M abadil H uda}

MI M abadil H uda is a private Islamic education institution located in C andi, Banjaran Village, Bangsri District, Jepara Regency. This madrasah was built by Sunni N ahdlatul U lama figures around 1935. This institution is the oldest MI in Bangsri District. Initially, this TPQ only accommodated children from NU backgrounds. However, after the Shia appeared in Banjaran Village, to be precise in Dukuh Candi in 1982, many Shia residents entrusted their children's I slamic education to M I M abadil H uda. This continues till now. The main objective of the MI M abadil H uda formal school is to shape the personalities of students to strengthen 
their morals and equip them with knowledge. Just like other schools, the learning materials include general, social, and religious materials (observations at MI M abadil H uda, M arch 2 , 2020) . NU culture is always taught to students. As explained by one of the following teachers:

Because Madrasa are Islamic schools, they apply more religious activities such as reading Asmaul Husna together every morning, praying dhuha in the congregation, praying dzuhur in the congregation, and every Thursday pilgrimage to the grave of M bah M uhammad Arif (interview with Zabidi, an Islamic religion teacher at M I M abadil H uda, Banjaran Village, M arch 2, 2020).

The purpose of implementing religious practices at M I M abadil $\mathrm{H}$ uda has indeed been implemented since its inception until now. This is to encourage students to get used to being obedient in worship and always living in harmony considering the number of students from different schools of thought.

Figure 4. The learning pro

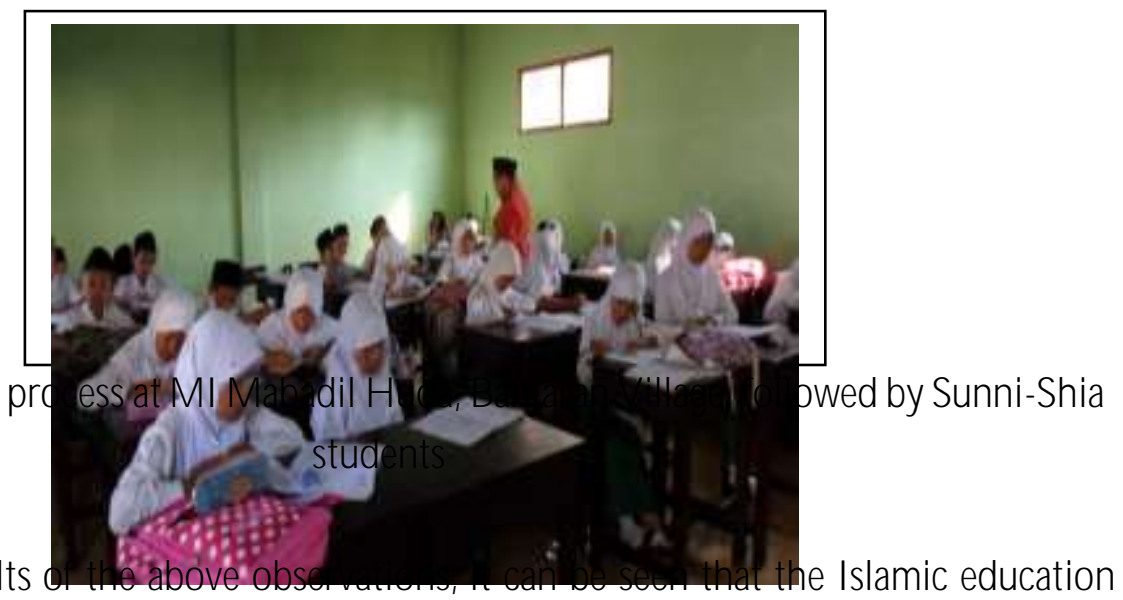

From the results

system is a collection of general principles about how educational institutions are organized to equip students' knowledge based on the Q ur'an and $\mathrm{H}$ adis. It is through the harmony of SunniShia Islamic religious education institutions in the community that multicultural awareness among residents is successfully constructed into the thinking of students. As explained by the following research informants:

Harmony in society cannot occur without the efforts of each individual or group. As much as I can, guide the people of Dukuh Candi and invite them to deepen their respective teachings. And getting to know other religions as knowledge, to be able to maintain the well-established harmony to date (interview with Zabidi, Guru MI M abadil H uda, 29 September 2019) .

The relationship between Sunnis and Shia in Banjaran Village is very different from other areas because there is never any friction between each other. Sunnis and Shiites maintain 
harmonious relations through various means. $\mathrm{H}$ istorically, the social pattern practiced by the Shia in Banjaran Village is different from the Shia in Bangsri Village. Although in fact, Shia in Bangsri Village is the teachers of the Banjaran Village Shia. H owever, because they do not want to live in a society and tend to close themselves off from society, Bangsri Shia people are left behind by the Shia who live in Banjaran Village. Socially, the majority of the M uslim Banjaran community is a pluralistic society in terms of organizational affiliation and religious sects. The people of Banjaran Village are members of many religious organizations, including NU ( $N$ ahdlatul U lama) and M uhammadiyah which represent the Sunni school of thought. There are also followers of the Shia school. However, in everyday life, these differences do not cause sentiment or jealousy. This is because the main enemy of the Sunnis is not another group like the Shia. But authoritarianism is absolute, whoever the perpetrators.

The most important thing is that we as Muslims must uphold the principles. Being hostile to forms of injustice and injustice, whoever the perpetrators are, whatever the motive is. Because, if we let the injustice take place, the impact will be on ourselves (interview with Zabidi, M I M abadil H uda teacher, 29 September 2019).

The concrete steps taken by Sunni-Shia residents in Banjaran Village to create multicultural awareness are as follows: 1) Dare to open up to each other and jointly dialogue the universal values of religious teachings. In Banjaran Village, for example, the first person to become a community role model is the figure of $M$ bah $M$ uhammad A rif. $H$ e is a Sunni M uslim figure who never tired of inviting people to live in harmony, side by side, and teaches concern about humanity. Every time there is a problem, it must be viewed with full wisdom. 2) Ethics in spreading religious teachings to the general public. The religious leaders in the Sunni- Shia community of Banjaran Village have their way of preaching and must not be provocative towards other religions. That is, they always uphold the rules of the game or ethical boundaries by avoiding a single truth claim from the group perspective. 3) Realizing that diversity is a natural law ( sunnatullah) which absolutely must be accepted.

Unfortunately, this research has not yet covered a broad portrait of Sunni-Shia religious education institutions throughout Jepara Regency and their relationship to the surrounding social environment. This kind of mapping is important to spread multicultural awareness behavior on a macro scale. Perhaps this step can be followed up by future researchers.

In contrast to TPQMa' arif 17 , multicultural awareness is taught by MI M abadil H uda teachers through both intra and extracurricular curricula. Tolerance towards peers, for 
example, is contained in Islamic Religious Education (PAI) lessons. As explained by Jamaluddin, the following Islamic C ultural H istory (SKI) teacher:

The Islamic Religious Education subject is developed by incorporating harmonizing values in it. The teacher uses effective learning methods adapted to tolerance material. Besides, tolerance is also expressed in various school activities, for example involving Sunni and Shia students in the Isra' Mi'raj of the Prophet M uhammad and a burial pilgrimage to the grave of $M$ bah M uhammad Arif, the founder of Banjaran Village (interview with Jamaluddin, the teacher of M I M abadil H uda, $6 \mathrm{M}$ arch 2021).

This is reinforced by the following statement by the $\mathrm{H}$ ead of $\mathrm{MI} \mathrm{M}$ abadil $\mathrm{H}$ uda:

In class VI, there is Fiqh material about the implementation of sermons. We provide students with an understanding of the differences in the implementation of Friday prayers between one group and another, complete with reasons. If it's Sunni like this. If it's Shia. The goal is that students respect each other for differences in beliefs (interview with M uchid, $\mathrm{H}$ ead of M I M abadil H uda, M arch 6, 2021).

A positive assessment of the Shia tradition can be seen from the appreciation of MI Mabadil Huda students in commemoration of religious holidays. Sunni-Shia students help each other prepare for organizing activities. However, they do not get involved in the ritual realm.

Students here are used to do activities together to commemorate Islamic holidays at school. Everyone helps each other. They are happy to do so because it can strengthen their brotherhood. But when it comes to rituals, different groups don't participate. At the time of the Ashura commemoration, for example, we Sunnis understand it to give permission not to go to school. The Sunni and the Shi'a are fine as long as we don't mix up our beliefs ( interview with M uchid, $\mathrm{H}$ ead of M I M abadil H uda, M arch 6, 2021).

Teachers also often provide advice on the importance of tolerance and lessons for differences. It is like what is written in Q ur'an surah al-Kafirun, "lakum diinukum waliyadiin" and in the hadith of Prophet Muhammad, "ikhtilaafu ummatii rahmatun".

\section{Conclusion}

The harmonious atmosphere between Sunni and Shia followers in Banjaran is reflected in the social and humanitarian works, organizations and religious educational institutions. This further proves that these kinds of activities must be instilled continuously and guarded by all religious and community leaders in Banjaran Village. Cultivating multicultural awareness in Sunni-Shia followers is useful to reduce tensions and the attitude of judging other groups. The people of Banjaran Village need the role of Sunni and Shia Islamic religious 
education institutions such as TPQ AI-H usainiah, TPQ Ma'arif $17 \mathrm{KH}$. M uhammad Arif, and MI M abadil H uda to preserve an inclusive climate and conducive tolerance. The multicultural education in TPQ and MI has different characteristics. The plurality awareness in TPQ tends to be inserted into the hidden curriculum so that it is not explicitly visible in the learning material. M eanwhile, the practice of multicultural learning in MI is more obvious, starting from curriculum content in the classroom to non-academic activities outside the classroom. Besides, the crucial factor that led to the strong Sunni-Shia relation in Banjaran Village was kinship. In one family, not a few of them have different understandings. So it can be concluded, apart from the role of educational institutions and inclusive culture of society, blood relations also make a significant contribution to Sunni-Shia harmony.

\section{REFERENCES}

Abdullah, M . A. (1996). Studi Agama: Normativitas atau H istorisitas?Pustaka Pelajar.

Amaliyah, E. I. (2015) . H armoni di Banjaran: Interaksi Sunni-Syiah. Jurnal M ultikultural \& Multireligius, 14(2), 81-96.

Amin, M., llyas, Y., Sam, I., \& Amirsyah. (2013). M engenal \& M ewaspadai Penyimpangan Syiah di Indonesia. Gema Insani.

Anis, M . (2015). Pemikiran Politik Syiah: Perspektif Wilayah al-Faqih. Pengantar Redaksi, 84.

Atharuddin, A. (2014). Syiah N usairiyyah; Sejarah, Ideologi, dan Ajarannya. Kalimah, 12(1), 13. https:// doi.org/ 10.21111/ klm.v12i1.225

Banks, J. A. ( 1998). The Lives and Values of Researchers: Implications for Educating Citizens in a M ulticultural Society. Educational Researcher, 27(7), 4-17.

Banks, J. A. (2001). Diversity within U nity: Essential Principles for T eaching and Learning in a M ulticultural Society. Phi D elta Kappa International, 83(3), 196-198,200-203.

Banks, J. A. (2014). M ulticultural Education: D evelopment, Dimensions, and Callenges. Phi Delta Kappa International, 75(1), 22-28.

Blanchard, C. M . (2010). Islam : Sunnis and Shiites. Congressional Research Service.

D oostmohammadi, A., M ousavi, S. A., \& Beigloo, J. A. S. (2012). A Study of the Causes of Wars between the Government and the Shiites of Yemen Based on "Fuzzy Cognitive Maps." Journal of International and A rea Studies, 19(1), 97-114.

Giroux, H. (1983). Theories of Reproduction and Resistance in the New Sociology of Education: A C ritical Analysis. H arvard Educational Review, 53(3), 257-294.

Gunawan, A. M. S. (2019). Politik Perlawanan Pengungsi Syiah Sampang Di Jemundo Dalam Pemenuhan Hak Sipil dan Politik. U N IVERSITAS AIRLAN GGA. 
H all, J. C., \& Theriot, M. T. (2016). D eveloping M ulticultural Awareness, Knowledge, and Skills: Diversity T raining M akes a Difference? Multicultural Perspectives, 18(1), 35_41. https:// doi.org/ 10.1080/ 15210960.2016.1125742

H ardiansyah, H . (2010). M etodologi Penelitian Kualitatif. Salemba H umanika.

H astuti, \& M aulana, H. F. (2019). Konflik Ideologi Syiah dan Sunni Dalam M edia O nline. Medialog: Jurnal IImu Komunikasi, I/(1), 31_40.

Hodari. (2015). Gerakan Politik Syiah-Sunni: Studi Kasus Konflik Kepemimpinan SyiahSunni di Desa Karang Gayam dan Desa Blu'uran Sampang Madura. UIN Sunan Ampel Surabaya.

Ida, R., \& Dyson, L. ( 2015). Konflik Sunni-Syiah dan dampaknya terhadap komunikasi intrareligius pada komunitas di Sampang-Madura. Masyarakat, Kebudayaan Dan Politik, 28(1), 33-49. https:// doi.org/ 10.20473/ mkp.v28i12015.33-49

Indonesia, T. A. (2012). Buku Putih Mazhab Syiah M enurut Para Ulamanya yang M uktabar. D ewan Pengurus Pusat Ahlulbait Indonesia.

Indonesia, T . A. (2014). Syiah M enurut Syiah. D ewan Pengurus Pusat Ahlulbait Indonesia.

Isya, M uhammad Andi. (2018). Pendidikan dan Konflik (Potret Konflik Sunni dan Syiah dan Imbasnya terhadap Pendidikan di Bangil Kabupaten Pasuruan). PRO GRESSA Journal of Islamic Religious Instruction, 2(1), 13-24.

Isya, Muhammad Andy. (2014). Disparitas Sunni dan Syiah Dalam Pendidikan: Studi Fenomenologi Lembaga Pendidikan Sunni Dan Syiah di Kabupaten Pasuruan. Diss. UIN Sunan Ampel Surabaya.

Izzah, N . I. (2020). U rgensi Pendidikan M ultikultural Di Indonesia Dalam Pendidikan Agama Islam. Al Hikmah: Journal of Education, 1(1), 35-46. http:/ / ejournal.yphn.ac.id/ index.php/ Alhikmah/ article/ view/ 5

Kadir, A. (2015). Syiah dan Politik: Studi Republik Islam Iran. JPP (Jurnal Politik Profetik), 3(1).

Khalilur Rahman. (2020). Syiah di Pekalongan: Studi Atas T radisi Syiah Pondok Pesantren AI $\mathrm{H}$ adi Pekalongan Jawa T engah. Religi: Jurnal Studi A gama-A gama, 16(1), 96-112.

Lynch, K. (2001). Creating a Dialogue Between Sociological and Egalitarian Theory in Education. International Studies in Sociology of Education, 11(3), 237-260. https:/ / doi.org/ 10.1080/ 09620210100200077

Mahmudah, H. (2017). Transmisi Ideologi Fundamentalisme dalam Pendidikan. TAJDID: Jurnal Pemikiran Keislaman Dan Kemanusiaan, 1(2), 200-216.

Marzuki, I. (2018). Lembaga Keagamaan, Pancasila, dan Strategi Pemberantasan Korupsi. Jurnal Yuridis, 5(2), 210-227. 
Masamah, U., \& Zamhari, M. (2016). Peran Guru Dalam Membangunan Pendidikan Berkesadaran Multikultural di Indonesia. QUALITY, 4(2), 271-289. https:/ / journal.iainkudus.ac.id/ index.php/ Q uality/ article/ view/ 2124

Mulyono, S. (2012). Pergolakan Teologi Syiah-Sunni: Membedah Potensi Integrasi dan Disintegrasi. Ulumuna Jurnal Studi Keislaman, 16(2), 275. https:// doi.org/ 10.1017/ CBO 9781107415324.004

Musolli. (2015). Ideologisasi M azhab Syiah di Balik Periodesasi Sejarah Tafsir AI-Qur'an. Empirisma, 24(1), 38-46.

Nur, S., \& Irmawati. (2019). Ideologi dan Gerakan Sosial Islam Syiah (Kajian Sosiologi Profetik) di Kota M akassar. Equilibrium: Jurnal Pendidikan, 7(1), 164-172.

Rakhmat, J. (2015). Akar Ideologis Konflik Sunni-Syiah. Ma'arif, 10(2), 68-83.

Reay, D. (2009). Sociology, Social Class, and Education. In The Routledge International $H$ andbook of the Sociology of Education (Issue D ecember, p. 402). Routledge.

Saefudin, A., \& Rohman, F. (2019a). Building Social H armony in the Jepara Shi'Ite Minorities. Journal of Contemporary Islam and Muslim Societies, 3(2), 176-204. https:/ / doi.org/ 10.30821/ jcims.v3i2.5622

Saefudin, A., \& Rohman, F. (2019b). Pendidikan Multikultural di Pondok Pesantren Syi'ah (Studi Kasus di Pondok Pesantren Darut Taqrib Jepara). Jurnal IImiah DIDAKTIKA, 19(1), 50-68. https:/ / doi.org/ 10.1017/ C BO 9781107415324.004

Sahide, A. (2013). Konflik Syi'ah-Sunni Pasca-The Arab Spring. KAWISTARA, 3(3), 227 334.

Samii, A. W. (2006). Shiites in Lebanon: The Key to Democracy. Middle East Policy, 13(2), 30-37.

Saparudin. (2017). Ideologi Keagamaan dalam Pendidikan: Diseminasi dan Kontestasi pada Madrasah dan Sekolah Islam di Lombok. In Sereal Untuk (Vol. 51, Issue 1). O nglam Books.

Sari, D., Yuminah, Y., \& H erlena, B. (2020). The Dynamics of Sunni and Shia Relationship: $M$ ajority and M inority Conflicts, in Psychological Perspective. Conference Paper, July. https:// doi.org/ 10.4108/ eai.7-11-2019.2294584

Sulaiman, S. (2017). Relasi Sunni-Syiah: Refleksi Kerukunan Umat Beragama di Bangsri Kabupaten Jepara. Panangkaran: Jurnal Penelitian Agama Dan Masyarakat, 1(1), 19-36. https:/ / doi.org/ 10.14421/ panangkaran.2017.0101-02

Wagemakers, J. (2020). Sectarianism in The Service of Salafism: Shiites as a Political Tool for Jordanian Salafis. British Journal of Middle Eastern Studies, 1-19. https:/ / doi.org/ 10.1080/ 13530194.2020.1805298 
Waterworth, J. A., Waterworth, E. L., M antovani, F., \& Riva, G. (2010). On Feeling (the) Present: An Evolutionary Account of the Sense of Presence in Physical and Electronically-M ediated Environments. Journal of Consciousness Studies, 17(1-2), 167_ 188.

Widyadara, R. T . (2015). Konflik Sunni-Syiah di Indonesia. Religi, X/(2), 109_124.

Wirata, W. (2018). H armonisasi antar U mat Beragama di Lombok. Pangkaja: Jurnal Agama Hindu, 21(1), 74-79.

Yumitro, G. (2017). Pengaruh Pemikiran dan Gerakan Politik Syiah Iran di Indonesia. Dauliyah Journal of Islamic and International Affairs, 2(2), 237. https:// doi.org/ 10.21111/ dauliyah.v2i2.1361

Yunus, F. M. (2014). Konflik Agama di Indonesia Problem dan Solusi Pemecahannya. Substantia, 16(2), 217-228.

Zafi, A. A. (2020). Penerapan Nilai-nilai M oderasi al-Qur'an dalam Pendidikan Islam. Jurnal Studi I/mu-I/mu Al-Qur'an Dan Hadis, 21( 1). https:// doi.org/ 10.14421/ Q H .2020.\%X 